\title{
Effect of Biological and Liquid Hot Water Pretreatments on Ethanol Yield from Mengkuang (Pandanus artocarpus Griff) ${ }^{1}$
}

\author{
Hikma Yanti ${ }^{2,3} \cdot$ Wasrin Syafii $\mathbb{D}^{2, \dagger} \cdot$ Nyoman $\mathrm{J}^{\text {Wistara }}{ }^{2} \cdot$ \\ Fauzi Febrianto ${ }^{2} \cdot$ Nam Hun Kim (iD ${ }^{4, \dagger}$
}

\begin{abstract}
This study aimed to increase the sugar and ethanol yield from the mengkuang plant biomass through biological and liquid hot water (LHW) pretreatment and their combination. The results showed that biological pretreatments with $5 \%$ inoculum of the fungus Trametes versicolor resulted in the highest alpha cellulose content incubated for 30 days, and $10 \%$ inoculum resulted in the lowest lignin content. LHW pretreatment decreased the hemicellulose content of pulps from $10.17 \%$ to $9.99 \%$. T. versicolor altered the structure of the mengkuang pulp by degrading the lignin and lignocellulose matrix. The resulting delignification and cellulose degradation facilitate the hydrolysis of cellulose into sugars. The alpha cellulose content after biological-LHW pretreatment was higher (78.99\%) compared to LHW-biological pretreatment (76.85\%). Scanning electron microscopy analysis showed that biological-LHW combinated treatment degrades the cell wall structures. The ethanol yield for biological-LHW pretreated sample was observed 43.86\% (13.11 g/L ethanol by weight of the substrate, which is much higher than that of LHW-biological pretreatment (34.02\%; 9.097 g/L). The highest reducing sugar content about $45.10 \%$ was observed with a resulting ethanol content of $15.5 \mathrm{~g} / \mathrm{L}$ at LHW pretreatment temperature of $180^{\circ} \mathrm{C}$ for $30 \mathrm{~min}$.
\end{abstract}

Keywords: biological, liquid hot water, ethanol, mengkuang (Pandanus artocarpus Griff), chemical and morphological changes

\section{INTRODUCTION}

The mengkuang plant belongs to the class of Monocotyledonae and family Pandanaceae (Heyne, 1987). Indonesia and other Asian countries use mengkuang leaves for making mats, baskets, and hats; how- ever stems are usually wasted. Mengkuang biomass contains a large amount of holocellulose (74.44\%), followed by alpha cellulose (42.81\%), and lignin (24.51\%) (Hadisuparto et al. 2011). This composition makes mengkuangas potential biomass and raw material for ethanol production.

\footnotetext{
1 Date Received September 28, 2018, Date Accepted February 12, 2019

2 Department of Forest Products, Faculty of Forestry, Bogor Agricultural University, IPB Darmaga Campus, Bogor, 16680, Indonesia

${ }^{3}$ Department of Forestry, Faculty of Forestry, Tanjungpura University, Jalan Imam Bonjol, Pontianak, 78124, Indonesia

${ }^{4}$ Department of Forest Biomaterials Engineering, College of Forest and Environmental Science, Kangwon National University, Chuncheon 24341, Republic of Korea

$\dagger$ Corresponding author: Wasrin Syafii (e-mail: wasrinsy@indo.net.id, ORCID: 0000-0002-2094-9307)

† Corresponding author: Nam Hun Kim (e-mail: kimnh@kangwon.ac.kr, ORCID: 0000-0002-4416-0554)
} 
The major chemical components of lignocellulosic materials are cellulose, hemicelluloses, and lignin (Heo et al., 2017). Cellulose and partly hemicellulose can be hydrolyzed into sugars and subsequently fermented into ethanol. The hydrolysis of cellulose into sugars is the principal step before saccharification of the resulting sugars into ethanol. However, the presence of lignin and crystalline nature of cellulose in the lignocellulosic materials complicate the chemical and enzymatic hydrolysis of the cellulose. Pretreatment is an important step in the process of ethanol production from lignocellulosic materials (Wang et al., 2008; Mosier et al., 2005). Pretreatment is applied to remove lignin, reduce cellulose crystallinity levels, increase enzyme contact surface areas, facilitate cellulose hydrolysis, and remove substances in the extract that can inhibit enzymatic and fermentation activities (Hendriks and Zeeman, 2009).

Biological pretreatment is effective and environmentally friendly pretreatment utilizes white rot fungus that reduces lignin levels and accelerates delignification (Chen et al., 2010, Zhang et al., 2007). Giles et al. (2011) emphasize the importannce of fungus selection in biological pretreatments to increase the delignification with increased selectivity.

Yu et al. (2012) and Gao et al. (2013) endorsed the use of LHW to separate lignocellulosic biomass (lignin and hemicellulose). LHW pretreatment produces cellulose fibers with degradaded products that can inhibit subsequent hydrolysis and fermentation processes. However, LHW pretreatment is adequate for partial removal of hemicellulose and lignin (Long et al., 2014).

Based on the abovementioned observations, various combined pretreatments options need to be investigated. A combination of hydrothermal and alkali pretreatments was assessed by Gao et al. (2013) using bagasse as raw material, and Long et al. (2014) examined a combination pretreatment using sorghum bagasse focusing on recycling hemicellulose for biorefineries.
Also, Cao et al. (2012) used alkali hydrogen peroxide pretreatment with autoclave heating for sweet sorghum.

The objective of this study is to increase the sugar and ethanol through degradation of mengkuang plant biomass by biological and LHW pretreatment combination. This report also investigate changes in its chemical and morphological characteristics of degraded products after the pretreatment.

\section{MATERIALS and METHODS}

\subsection{Preparation of raw materials}

Mengkuang (Pandanus artocarpus Griff) chips size used in this study are $12-25$ millimetres in length and 2 - 10 millimetres in thickness. It was collected from West Kalimantan, Indonesia. Delignification was performed using $\mathrm{NaOH}$ concentrations of $25 \%$ at a temperature of $170^{\circ} \mathrm{C}$ for $4 \mathrm{~h}$ (TAPPI 1997). The resulting pulp was washed and dried. The mengkuang pulp was then used as a raw material for biological and liquid hot water pretreatments.

\subsection{Biological pretreatment}

Biological pretreatment was carried out as described by Fatriasari et al. (2014). An innoculum of T. versicolor was cultured on medium extract agar (MEA; $8.875 \mathrm{~g}$ MEA dissolved in $250 \mathrm{~mL}$ of aquadest) for 14 days. A total of $5 \mathrm{~mL}$ of JS broth (3 $\mathrm{g}$ of $\mathrm{KH}_{2} \mathrm{PO}_{4}, 2 \mathrm{gMgSO}_{4}$. $7 \mathrm{H}_{2} \mathrm{O}$, 25g glucose, $5 \mathrm{~g}$ peptone, and $10 \mathrm{~g}$ malt extract in $1 \mathrm{~L}$ aquadest) was placed into each slant, the fungus then threshed with a needle. The suspension was then poured into $95 \mathrm{~mL}$ of JIS broth and incubated for 7-8 days without shaking. $10 \mathrm{~g}$ of corn steep liquor was then poured into $100 \mathrm{~mL}$ of inoculum, then homogenized with an HGB TWT Waring blender at high speed (22,000 RPM) for $20 \mathrm{~s}$, and this homogeneous mixture was used as the stock inoculum.

$15 \mathrm{~g}$ of mengkuang pulp was sterilized using 
autoclave at $121^{\circ} \mathrm{C}$ and $1 \mathrm{~atm}$ pressure for $20 \mathrm{~min}$. The pulp was cooled and then inoculated with inoculum at of $5 \%$ or $10 \%(\mathrm{v} / \mathrm{w})$. After inoculation, the mengkuang pulp was incubated at $27^{\circ} \mathrm{C}$ and $73 \%$ humidity for 15 , 30, or 45 days.

\subsection{LHW pretreatment}

The LHW pretreatment was carried out as described by Yu et al. (2013), Yu et al. (2012), Yu et al. (2011) and $\mathrm{Li}$ et al. (2013) with some modifications. The mengkuang pulp (100 g) was placed into a digester and then added to a solid to liquor ratio 1:20. The digester was heated to $140^{\circ} \mathrm{C}, 160^{\circ} \mathrm{C}$, and $180^{\circ} \mathrm{C}$ for 20, 30, and $40 \mathrm{~min}$, respectively. The pulp sample was then washed with $100 \mathrm{~mL}$ of hot water and filtered to separate the residue and hydrolysate. The residue was then rinsed with aquadest until colorless and a $\mathrm{pH}$ of 7 , and then stored in a sealed plastic container in the refrigerator. The pretreated pulp was then used for simultaneous saccharification and fermentation (SSF) and characterization using FTIR and SEM.

\subsection{Combination pretreatment}

There were two combination pretreatments were reported in this study. In the first, biological pretreatment preceded by LHW pretreatment, while in the second, the order was reversed.

\subsection{Determination of chemical components}

The holocellulose content was determined according to the procedure of Browning (1967), alpha cellulose by TAPPI T9 $\mathrm{m}$ - 54, lignin content by TAPPI T 222 om-88 and according to Dence (1992), and acid soluble lignin by TAPPI T-250. Hemicellulose content is calculated by the reduction of alpha cellulose content from the holocellulose content (Punyamurthy et al. 2013). Selectivity value is a ratio between weight loss of lignin against weight loss of cellulose (Yu et al. 2009).

Selectivity value $=\frac{\text { Weight Loss of lignin }}{\text { Weight Loss of Cellulose }} \ldots \ldots \ldots . . . .$.

\subsection{Chemical composition and morphological structure}

Changes in chemical composition of pretreated pulp were assessed by FTIR evaluation (TENSOR 37) and measured the weight loss of lignin, cellulose, and hemicellulose in the sample. Weight loss was determined using the method of Pandey and Pitman (2003), whereas the selectivity of delignification was calculated based on the ratio of lignin loss to cellulose loss, as reported by Yu et al. 2010. Biodegradation patterns and changes in the morphological characteristics of the pretreated pulp, were evaluated using SEM JEOL-JSM-6510.

\subsection{Simultaneous saccharification and fermentation}

SSF was performed using the NREL method (Dowe and McMillan, 2008). A mixture of pretreated pulp and sodium citrate buffer solution was sterilized by autoclave at $121^{\circ} \mathrm{C}$ for $15 \mathrm{~min}$ and then cooled. $3 \mathrm{~mL}$ of Saccharomyces cerevisiae inoculum was then added with 0.3 g yeast extract, $0.2 \mathrm{~g}$ peptone, $2.2 \mathrm{~mL}$ of 1 $\mathrm{M}$ sodium citrate buffer ( $\mathrm{pH} 4.8$ ), cellulase enzyme with a dosages of $1.96 \mathrm{~mL}$ and $10 \%$ yeast inoculum up to $50 \mathrm{~mL}$ of fermentation volume. The material was then incubated for $72 \mathrm{~h}$ at $38^{\circ} \mathrm{C}$ at $150 \mathrm{rpm}$. Ethanol content was subsequently evaluated using gas chromatography, and the yield was calculated using the procedure described by Wistara et al. (2015). Ethanol yield was calculated based on ethanol concentration (\%, v/v) $\times$ fermentation volumn divided by wood pulp dry weight, while cellulose conversion was calculated 
based on ethanol concentration divided by (pulp (g/L) $\times$ cellulose fraction $(\mathrm{g} / \mathrm{L}) \times 1.111 \times 0.51)$ multiplied by $100 \%$ (with 1.111 being the equivalent conversion factor of cellulose to glucose, and 0.51 is the conversion factor of glucose to ethanol).

Ethanol yield $(\%, \mathrm{v} / \mathrm{w})=$

Ethanol concentration $(\%, \mathrm{v} / \mathrm{v}) \times$ fermentation volumn

$$
\text { pulp dry weight }
$$

Cellulose conversion $(\%)=$

Ethanol concentration $(\mathrm{g} / \mathrm{L})$

pulp $(\mathrm{g} / \mathrm{L}) \times$ cellulose fraction $(\mathrm{g} / \mathrm{L}) \times 1.111 \times 0.51$

\subsection{Reducing sugars}

Reducing sugar content was determined using the dinitrosalicylic acid (DNS) reagent method with glucose for a standard curve and by measuring absorbance at $540 \mathrm{~nm}$. Glucose standard was prepared by diluting a pure glucose stock solution $(10 \mathrm{mg} / \mathrm{mL})$ in water at different ratios (1: $1.5 ; 1: 2 ; 1: 3 ; 1: 5) .1 \mathrm{~mL}$ of each glucose solution was placed into the test tube and 3 $\mathrm{mL}$ of DNS reagent added. The samples were heated in boiling water for $5 \mathrm{~min}$ and then cooled in an ice bath. $1 \mathrm{~mL}$ of water was used for the blank.

For that analysis, $400 \mu \mathrm{L}$ was added to a reaction tube containing $1 \mathrm{~mL}$ of aquadest, and then treated in the same way as the standards. Five hundred $\mu \mathrm{L}$ of each sample was then added to $1 \mathrm{~mL}$ of water before the measurement of absorbance. Sample concentrations were determined by reference to the glucose standard curve.

\section{RESULTS and DISCUSSION}

\subsection{Changes in chemical components}

\subsubsection{Chemical components after biological pretreatment}

The changes observed to chemical components of mengkuang after biological pretreatment are depicted in Table 1. The high content of cellulose and hemicellulose indicates that the plant has potential as a bioethanol feedstock. However, its relatively high lignin content could inhibit the hydrolysis process, therefore it needs to be removed before hydrolysis.

During delignification, carbohydrates such as alphacellulose are also degraded. This may be due to partial disruption of hydrogen bonds in the lignin-carbohydrate complex (LCC), as reported by Li et al. (2010). Biological pretreatment elicits the opening of the complex structure of lignocellulose through lignin depolymerization, resulting in increased accessibility to the carbohydrate. The white rot fungus used in biological

Table 1. chemical components of mengkuang pulp after biological pretreatment.

\begin{tabular}{cccccccc}
\hline $\begin{array}{c}\text { inoculum } \\
(\%)\end{array}$ & $\begin{array}{c}\text { incubation } \\
(\text { day })\end{array}$ & $\begin{array}{c}\text { holocellulose } \\
(\%)\end{array}$ & $\begin{array}{c}\alpha \text { cellulose } \\
(\%)\end{array}$ & $\begin{array}{c}\text { hemicellulose } \\
(\%)\end{array}$ & $\begin{array}{c}\text { klason lignin } \\
(\%)\end{array}$ & $\begin{array}{c}\text { acid soluble } \\
\text { lignin }(\%)\end{array}$ & $\begin{array}{c}\text { lignin total } \\
(\%)\end{array}$ \\
\hline \hline 0 & 0 & 91.49 & 82.27 & 9.22 & 10.87 & 2.09 & 12.96 \\
5 & 15 & 91.02 & 76.70 & 14.32 & 9.46 & 0.99 & 10.45 \\
& 30 & 95.62 & 84.11 & 11.51 & 7.08 & 1.44 & 8.52 \\
& 45 & 88.12 & 73.31 & 14.81 & 10.84 & 0.67 & 11.51 \\
\hline 10 & 15 & 86.01 & 77.45 & 8.56 & 9.74 & 0.61 & 10.35 \\
& 30 & 92.35 & 83.24 & 9.11 & 6.52 & 1.31 & 7.83 \\
& 45 & 82.39 & 72.36 & 10.03 & 10.84 & 0.50 & 11.34 \\
\hline
\end{tabular}


pretreatment degrades lignin polymers through enzymatic attacks (Zhang et al., 2007; Hong et al., 2016), that also affect the reduction of reducing sugars.

The extension of incubation time tended to decrease the weight loss of the chemical components in the $10 \%$ inoculum. This is likely associated with greater loss of lignin than that of carbohydrate, since the fungi were more capable of degrading lignin than carbohydrates. A higher selectivity value for delignification indicates that a process is most effective. The selectivity values of the 5 and $10 \%$ inoculant at 30 days indicated better selectivity than those incubated for 15 and 45 days. There was a significant increase in the selectivity value of delignification upon increasing the incubation time for 30 days, which indicated that the fungus had a more selective lignin degradation ability. The selectivity value of the mengkuang pulp after pretreatment decreased after 30 days of incubation. These results indicate that T. versicolor is more selective at degrading lignin only in the concentration of inoculum of pretreatment; however less selective with increasing incubation time. The results of this study are consistent with those of Nazarpour et al. 2013 and Ferraz et al. 2008, who used pretreatment with $T$. versicolor on rubber wood and pretreatment with a mix of $T$. versicolor and Ceriporiopsis subvermisphora or with Ganoderma austrael on Pinus radiate wood, respectively. These results are also consistent with those of Fatriasari et al. (2011) and Falah et al. (2011), who applied T. versicolor to Betung bamboo in a 45-day biopulping process that provided better delignification compared to pretreatment with Pleorotus ostreatus and Phenerochaete chrysosporium.

\subsubsection{LHW pretreatment}

Similar to biological pretreatment, LHW pretreatment also caused chemical changes in the samples (Table 2). Cellulose can be hydrolyzed to reducing sugar which is then fermented into ethanol. LHW pretreatment not only dissolves hemicellulose but also degrades lignin. The application of LHW pretreatment to alkaline pulp caused a decrease in the level of lignin to lignin before the LHW pretreatment. In general, this combination of LHW pretreatment has a more effective effect in reducing lignin levels. The highest alpha cellulose content at a temperature of $160{ }^{\circ} \mathrm{C}$ for 30 minutes was $77.45 \%$. The combination of temperature and time treatment causes the degradation of amorphous components (lignin and hemicellulose). LHW pretreatment of mengkuang for 30 min promotes dissolution of lignin and hemicellose which affects the alpha cellulose content in a temperature dependent manner. The amorphous

Table 2. Chemical components of mengkuang pulp after LHW pretreatment.

\begin{tabular}{ccccccc}
\hline $\begin{array}{c}\text { Temperature } \\
\left({ }^{\circ} \mathrm{C}\right)\end{array}$ & $\begin{array}{c}\text { Duration } \\
(\text { minutes })\end{array}$ & $\begin{array}{c}\text { Alpha cellulose } \\
(\%)\end{array}$ & $\begin{array}{c}\text { Hemicellulose } \\
(\%)\end{array}$ & $\begin{array}{c}\text { Klason Lignin } \\
(\%)\end{array}$ & $\begin{array}{c}\text { Acid Soluble } \\
\text { Lignin }(\%)\end{array}$ & $\begin{array}{c}\text { Lignin Total } \\
(\%)\end{array}$ \\
\hline \hline Control & 0 & 77.89 & 10.32 & 9.79 & 2.01 & 11.80 \\
\hline 140 & 20 & 67.60 & 9.59 & 7.70 & 0.67 & 8.37 \\
& 30 & 73.32 & 9.06 & 6.67 & 1.29 & 7.96 \\
& 40 & 66.23 & 9.25 & 7.08 & 0.77 & 7.85 \\
\hline 160 & 20 & 68.97 & 8.96 & 7.76 & 0.69 & 8.45 \\
& 30 & 77.45 & 9.93 & 6.32 & 1.50 & 7.82 \\
& 40 & 67.45 & 9.93 & 8.01 & 0.75 & 8.76 \\
\hline 180 & 20 & 67.23 & 5.90 & 7.94 & 0.63 & 8.57 \\
& 30 & 76.24 & 9.77 & 6.65 & 1.08 & 7.73 \\
\hline
\end{tabular}


portion of cellulose can be degraded at temperatures less than $150{ }^{\circ} \mathrm{C}$ while the new crystalline part can be degraded at a temperature of at least $180{ }^{\circ} \mathrm{C}$.

LHW pretreatment also decreased the hemicellulose content of sample pulp from $10.17 \%$ to $9.99 \%$, indicating that an increase in temperature is capable of degrading the hemicellulose component of the mengkuang pulp. Zhuang et al. (2015) suggested that the use of high temperatures in pressurized digesters causes the depolymerization of hemicellulose within the LHW liquid fraction. Structurally, this polymer has a chain that branches with a low degree of polymerization, making it easy to react. The process of hemicellulose dissolution during the LHW process comprises three stages, first reaction on the surface of the biomass, dissolution of the primary product in water, and decomposition of the primary product (Zhuang et al., 2015). LHW pretreatment of bagasse reduces lignin content by $20-30 \%$, and high hemicellulose derived sugars recovery of $75.5 \%$ and glucose recovery of $87 \%$ (Yu et al., 2013). These physical effects affect the chemical composition of bagasse, since degradation of lignin facilitates the dissolution of carbohydrates, particularly hemicellulose (Fajriutami et al., 2016), and a decrease in lignin content is also expected to facilitate hydrolysis, as reported by Michelin and Teixeira (2016),
Wang et al. (2016), and Yang et al. (2017).

A study carried out by Yu et al. (2013) showed that the LHW pretreatment of bagasse promoted hemicellulose dissolution at 20 min, which affects the concentration of xylose in the liquid fraction and temperature-dependent manner. Xylose content increased with increasing temperature up to $180^{\circ} \mathrm{C}$ and then decreased. This xylose concentration reached a maximum at $160^{\circ} \mathrm{C}$ up to $74.3 \%$. Furthermore, xylose and glucose decomposition at this temperature resulted in the formation of furfural and 5-hydroxymethylfurfural (5-HMF; Yu et al., 2011). Branched chain structures and a low degree of polymerization cause the hemicellulose polymer to be degraded more easily than cellulose, and the loss of some hemicellulose. This effect could have a positive impact on subsequent levels of cellulose hydrolysis by enzymes (Hendrik and Zeeman 2009), thus affecting the increase of Reducing Sugar Yield (RSY).

\subsubsection{Combination of Biological-LHW and LHW-biological pretreatments}

Biological-LHW pretreatment left $78.99 \%$ of the alpha cellulose in the mengkuang pulp, whereas LHWbiological left 76.85\% (Table 3 and 4). A high degree of lignin degradation was observed compared to cellulose degradation (Table 3 and 4).

Table 3. Chemical components of mengkuang pulp after biological-LHW pretreatment.

\begin{tabular}{cccccccc}
\hline $\begin{array}{c}\text { Temperature } \\
\left({ }^{\circ} \mathrm{C}\right)\end{array}$ & $\begin{array}{c}\text { Duration } \\
\text { (minutes) }\end{array}$ & $\begin{array}{c}\text { Holocellulose } \\
(\%)\end{array}$ & $\begin{array}{c}\text { Alpha } \\
\text { Cellulose }(\%)\end{array}$ & $\begin{array}{c}\text { Hemicellulose } \\
(\%)\end{array}$ & $\begin{array}{c}\text { Klason } \\
\text { Lignin (\%) }\end{array}$ & $\begin{array}{c}\text { Acid Soluble } \\
\text { Lignin }(\%)\end{array}$ & $\begin{array}{c}\text { Lignin Total } \\
(\%)\end{array}$ \\
\hline \hline Control & 0 & 92.14 & 81.25 & 10.89 & 8.97 & 2.02 & 10.99 \\
\hline 140 & $140 ; 20$ & 79.76 & 69.85 & 9.91 & 7.57 & 0.59 & 8.16 \\
& $140 ; 30$ & 85.58 & 75.63 & 9.95 & 6.34 & 1.06 & 7.40 \\
& $140 ; 40$ & 76.48 & 68.13 & 8.35 & 6.98 & 0.68 & 7.66 \\
\hline 160 & $160 ; 20$ & 78.98 & 68.99 & 9.99 & 7.06 & 0.60 & 7.66 \\
& $160 ; 30$ & 88.98 & 78.99 & 9.99 & 6.08 & 1.35 & 7.43 \\
& $160 ; 40$ & 77.88 & 67.98 & 9.90 & 7.91 & 0.71 & 8.62 \\
\hline 180 & $180 ; 20$ & 75.65 & 67.02 & 8.63 & 7.82 & 0.54 & 8.36 \\
& $180 ; 30$ & 87.22 & 77.41 & 9.81 & 6.45 & 1.01 & 7.46 \\
& $180 ; 40$ & 72.85 & 63.42 & 9.43 & 8.09 & 0.69 & 8.78 \\
\hline
\end{tabular}


Effect of Biological and Liquid Hot Water Pretreatments on Ethanol Yield from Mengkuang (Pandanus artocarpus Griff)

Table 4. Chemical components of mengkuang pulp after LHW- biological pretreatment.

\begin{tabular}{ccccccc}
\hline $\begin{array}{c}\text { Inoculum } \\
\begin{array}{c}\text { concentration } \\
(\%)\end{array}\end{array}$ & $\begin{array}{c}\text { Incubation time } \\
\text { (days) }\end{array}$ & $\begin{array}{c}\text { Alpha cellulose } \\
(\%)\end{array}$ & $\begin{array}{c}\text { Hemicellulose } \\
(\%)\end{array}$ & $\begin{array}{c}\text { Klason Lignin } \\
(\%)\end{array}$ & $\begin{array}{c}\text { Acid Soluble } \\
\text { Lignin (\%) }\end{array}$ & $\begin{array}{c}\text { Lignin Total } \\
(\%)\end{array}$ \\
\hline \hline 0 & 0 & 81.07 & 12.96 & 11.38 & 1.98 & 13.36 \\
\hline 5 & 15 & 62.94 & 11.78 & 10.61 & 0.62 & 11.23 \\
& 30 & 65.71 & 11.06 & 9.93 & 0.55 & 10.48 \\
& 45 & 69.32 & 10.09 & 8.70 & 0.62 & 9.33 \\
\hline 10 & 15 & 68.73 & 10.69 & 8.07 & 0.58 & 8.65 \\
& 30 & 73.10 & 7.82 & 7.73 & 0.54 & 8.27 \\
& 45 & 76.85 & 7.81 & 7.26 & 0.64 & 7.90 \\
\hline
\end{tabular}

The alpha cellulose content after biological-LHW pretreatment increased as a result of the breakdown of the biomass structure from the disruption of hydrogen bonds and intermolecular binding to lignin. Carbohydrates (alpha cellulose) are degraded effectively due to the partial disruption of hydrogen bonds in the LCC that occurs during delignification (Li et al., 2010). The opening of the complex structure of lignocellulose through lignin depolymerization by the biological pretreatment results in increased accessibility to the carbohydrate.

The main effects of this combination pretreatment, it allows to increase lignin and hemicellulose degradation and thus increased fiber porosity leads to decrease hemicellulose and lignin content by $1.69 \%$ and $3.83 \%$, respectively. Loss of lignin is an important indicator in the assessment of the effectiveness of pretreatment methods for bioethanol production, with larger lignin losses leading to more ethanol production. Hemicellulose forms covalent bonds with lignin and so part of the hemicellulose will be lost if the lignin is degraded (Siera et al., 2009; Hendrik and Zeeman, 2009). This combination of pretreatments is complex because the biological pretreatment degrades lignin while the LHW pretreatment degrades hemicellulose. So, the chemical components of the mengkuang pulp can be changed (Nazarpour et al., 2013, Ferraz et al., 2008; Zhuang et al., 2015).

\subsection{Changes in cellulose structure and morphology after pretreatment}

\subsubsection{Biological pretreatment}

FTIR analysis showed that biological pretreatment only affects the intensity of the functional group bands without altering any functional groups. Strong hydroxyl $(\mathrm{OH})$ bonds were visible at $3417 \mathrm{~cm}^{-1}$, and C-H bonds appeared at approximately $2920 \mathrm{~cm}^{-1}$. Several peaks were found in the fingerprint area between 1750 and $800 \mathrm{~cm}^{-1}$. The peaks were at $1648 \mathrm{~cm}^{-1}$ for the unconjugated $\mathrm{C}=\mathrm{O}$ in xylan (hemicellulose), 1635 $\mathrm{cm}^{-1}$ for absorbed $\mathrm{OH}$ and conjugated $\mathrm{CO}, 1605 \mathrm{~cm}^{-1}$ for the skeletal aromatic group of lignin, $1058 \mathrm{~cm}^{-1}$ for CO ester bonds, $1378 \mathrm{~cm}^{-1}$ for $\mathrm{C}=\mathrm{C}$ bonds, 2902 $\mathrm{cm}^{-1}$ for $\mathrm{CH}$ aliphatic bonds, and $2383 \mathrm{~cm}^{-1}$ for $\mathrm{CH}$ aldehydes (Fig. 1).

According to Pandey and Pitman (2003), the lignin band peak at $1512 \mathrm{~cm}^{-1}$ (aromatic group) decreases after sample pretreatment because of the release of lignin from the lignocellulosic matrix, thus the intensity of lignin peaks significantly decreases compared with that of carbohydrates (Nazarpour et al., 2013).

\subsubsection{LHW pretreatment}

FTIR revealed absorbance at $3397 \mathrm{~cm}^{-1}$ (Fig. 2), representing absorption by hydrogen group stretch (O-H). According to Pandey and Pitman (2003), the 


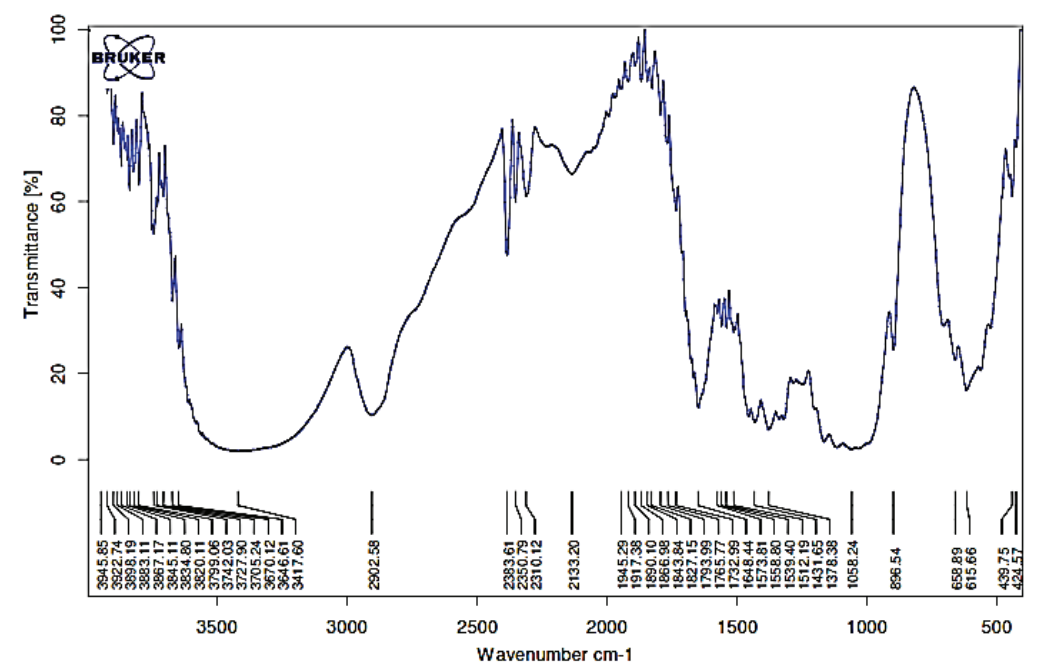

Fig. 1. FTIR spectra of mengkuang pulp after biological pretreatment.

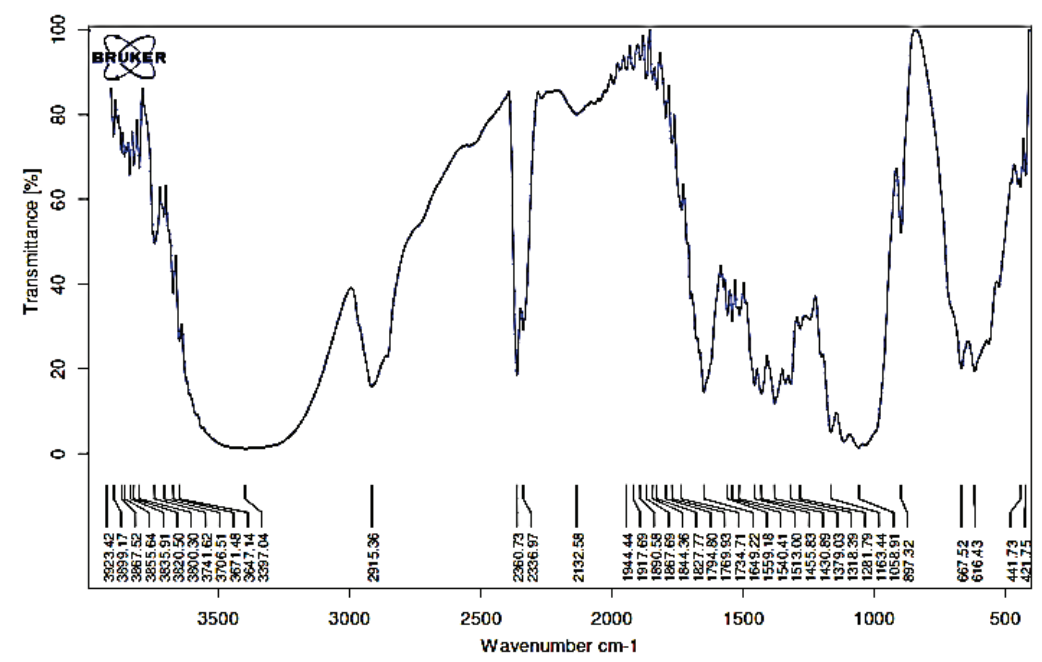

Fig. 2. FTIR spectra of mengkuang pulp after LHW pretreatment.

bands at $2700-2901 \mathrm{~cm}^{-1}$ correspond to C-H strain. LHW pretreatment had an effect on the peak area and height at $3397 \mathrm{~cm}^{-1}$ (O-H strain) as indicated attenuation of intra- and intermolecular hydrogen bonds (Goshadrou et al., 2011).

The absorption between $1600-1510 \mathrm{~cm}^{-1}$ in FTIR spectra is due to aromatic group vibration, and peaks between 1470 and $1460 \mathrm{~cm}^{-1}$ (C-H deformation and aromatic group vibrations) are an indication of lignin structure (Fengel and Wegener, 1995). The indications of the existence of the lignin structure in this pretreatment will affect the hydrolysis process. Wavenumber $1649 \mathrm{~cm}^{-1}$ for $\mathrm{C}=\mathrm{O}, 1058 \mathrm{~cm}^{-1}$ for $\mathrm{CO}$ ester, $1379 \mathrm{~cm}^{-1}$ for $\mathrm{C}$ $=\mathrm{C}, 2915 \mathrm{~cm}^{-1}$ for $\mathrm{CH}$ aliphatic and $2360 \mathrm{~cm}^{-1}$ for $\mathrm{CH}$ aldehyde was observed evidently (the aldehyde functional group allows the sugar to act as a reducing agent on 


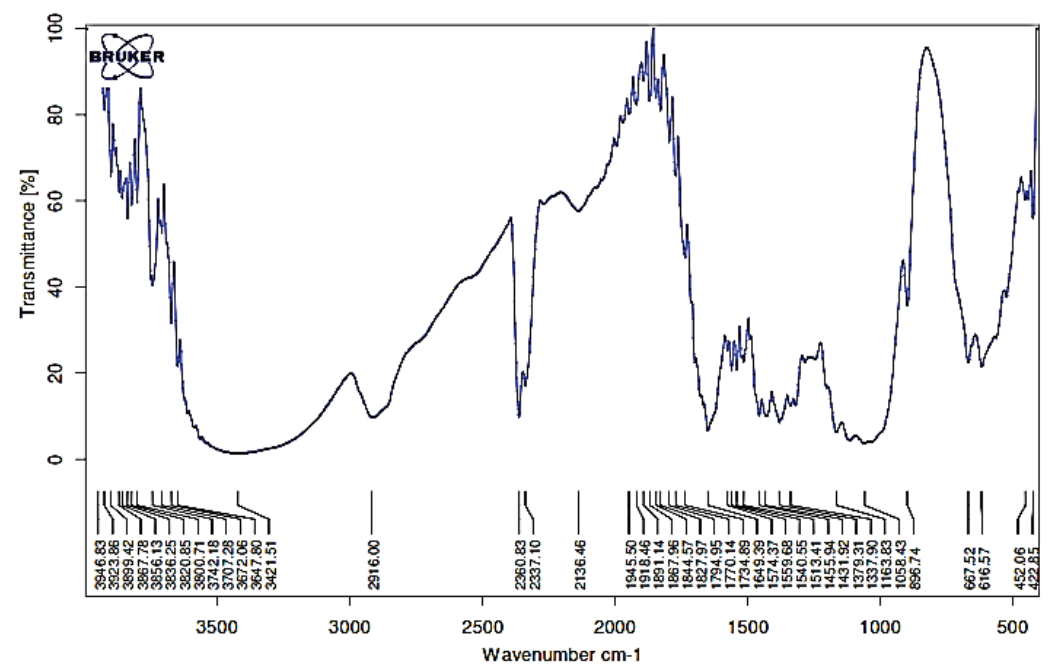

Fig. 3. FTIR spectra of mengkuang pulp after biological-LHW pretreatment.

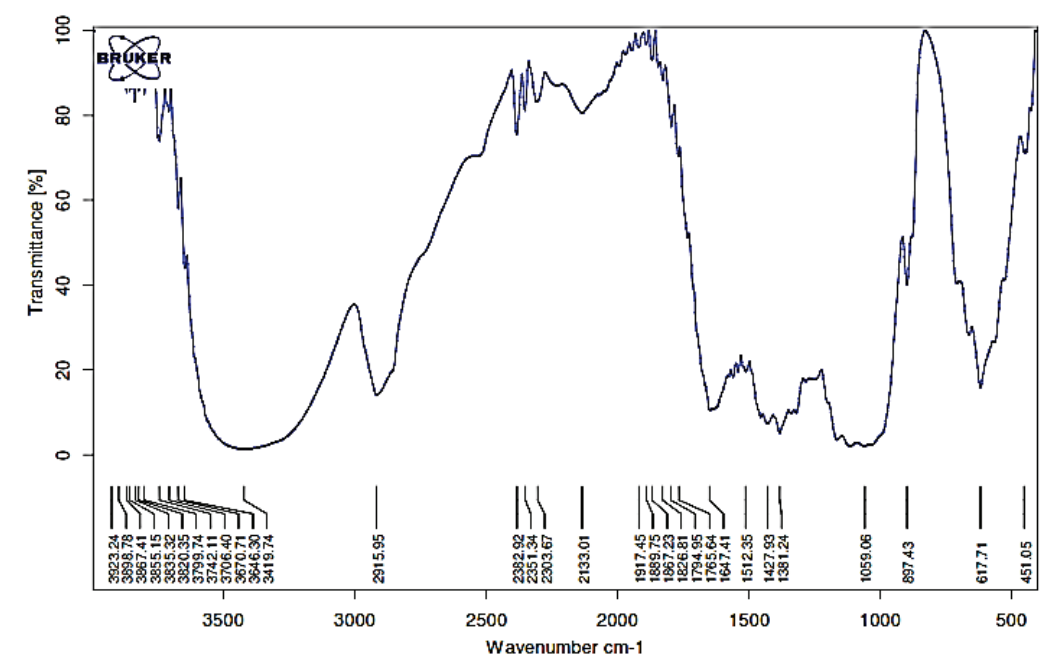

Fig. 4. FTIR spectra of mengkuang pulp after LHW-biological pretreatment.

reducing sugar). It is because of double pretreatment used (biological-LHW and LHW-biological).

\subsubsection{Combination of Biological-LHW and LHW-biological pretreatment}

Broad FTIR absorbance occurred at $3421 \mathrm{~cm}^{-1}$ indicating absorption by hydrogen group strain $(\mathrm{O}-\mathrm{H})$. Fig. 3 explains that biological-LHW pretreatment has an effect on the peak area and height at $3421 \mathrm{~cm}^{-1}$ as indicated by the attenuation of intra and intermolecular hydrogen bonds (Goshadrou et al., 2011). The area at $3000-2600 \mathrm{~cm}^{-1}$ was identical to the $\mathrm{O}-\mathrm{H}$ strain region of cellulose and the wavebands at 2700-2922 $\mathrm{cm}^{-1}$ correspond to $\mathrm{C}-\mathrm{H}$ strain (Pandey and Pitman, 2003). Spectrum with 1649 and $1734 \mathrm{~cm}^{-1}$ was observed for the unconjugated $\mathrm{C}=\mathrm{O}$ (aromatic ring vibration) in xylan $1741 \mathrm{~cm}^{-1}$ and indicating hemicellulose degradation during delignification, indication of lignin structure 
seen in wave $1455 \mathrm{~cm}^{-1}$ ( $\mathrm{CH}$ and vibration of aromatic rings) (Fengel and Wegener 1995). Lignin in mengkuang pulp comprises of guaiacyl (G) (1281), syringyl (S) (1318), and p-hydroxyphenyl (P) units, wave number $1058 \mathrm{~cm}^{-1}$ for CO ester, wave band $1379 \mathrm{~cm}^{-1}$ for the $\mathrm{C}=\mathrm{C}$, and wave number $2916 \mathrm{~cm}^{-1}$ for $\mathrm{CH}$ aliphatic and $2360 \mathrm{~cm}^{-1}$ for the stretching of $\mathrm{CH}$ aldehyde. A decrease in absorbance at 1318 and $1281 \mathrm{~cm}^{-1}$ occurred along with increasing LHW duration, indicating a decrease in lignin levels. Fig. 2 shows that syringyl lignin absorbance was lower than that of the guaiacyl form, indicating that the syringyl form was more soluble.

Band peaks at wavelengths around $896 \mathrm{~cm}^{-1}$ indicate $\beta$-glycoside bonds between sugar units in cellulose (Nelson and Connor 1964) as shown in Figs. 3 and 4, and these showed an increasing cellulose content in the sample. This increasing of cellulose content was caused by the loss of the lignin that forms the matrix with cellulose. Increasing incubation time resulted in a decrease in the intensity of the wave band of the $\mathrm{C}=\mathrm{O}$ functional group, $\mathrm{C}-\mathrm{H}$ in cellulose and hemicellulose, and C-O-C in hemicellulose. Twelve functional groups could be observed after the biological -LHW and LHW-biological combination pretreatments. Biologic-LHW pretreatment also caused a decrease in the intensity of peak absorbance of $\mathrm{CH}$ aldehyde (2360 $\mathrm{cm}^{-1}$ ). The delignification and cellulose damage observed should facilitate the hydrolysis process of converting cellulose into sugars.

\subsection{Morphological characteristics}

\subsubsection{Biological pretreatment}

The sample used for investigation of morphological characteristics was the one that resulted from the best pretreatment conditions with 30 days of incubation. The white rot fungi clearly caused damage to the mengkuang fibers (Fig. 5). Uncoated fungicides exhibited compact particle structures, whereas pretreated mengkuang pulps exhibited damaged fiber structures. The matrix on the damaged cell walls corresponds to the depolymerization of lignin and the dissolution of hemicellulosic polymer (Ramos, 2003).

Biological pretreatment causes lignin degradation that can increase pore size in the substrate, increasing the surface area and making it more readily accessible to cellulase enzyme. Biological pretreatment also causes some fibers to separate due to the breakdown of some ether bonds in lignin as well as carbohydrate bonds. Pretreatment causes damage to crystalline cellulose, which would make it more hydrolyzable.

\subsubsection{LHW pretreatment}

SEM images of samples pretreated at 140, 160, and $180^{\circ} \mathrm{C}$ indicated that there was slight damage to the fiber structure and swelling of the cell walls (Fig. 6). This indicates that some of the lignin and hemicellulose components had been degraded, resulting in a larger cellulose surface area (Hu and Wen, 2008). The breakdown of lignin and hemicellulose polymers within the cell wall occurs due to the pretreatment given to the morphology of the fibers. The degree of fiber damage grew worse with increasing temperature and duration. Morphological changes to the cell wall occur due to loss of lignin and result in enlargement of pore sizes at the surface of the fiber; this increases enzyme penetration into the cellulose. Degradation of lignin and hemicellulose can damage the ether bonds in lignin and lignin-carbohydrate complexes and so encourage the separation of fibers (Li et al., 2010) and cellulose digestibility can be enhanced by lignin breakdown (Nazarpour et al., 2013). The mengkuang pulp structure fills after LHW pretreatment can also result in more open and fragile structures that can increase the rate of subsequent hydrolysis reactions.

\subsubsection{Combination of pretreatments}

SEM revealed considerable differences between the 

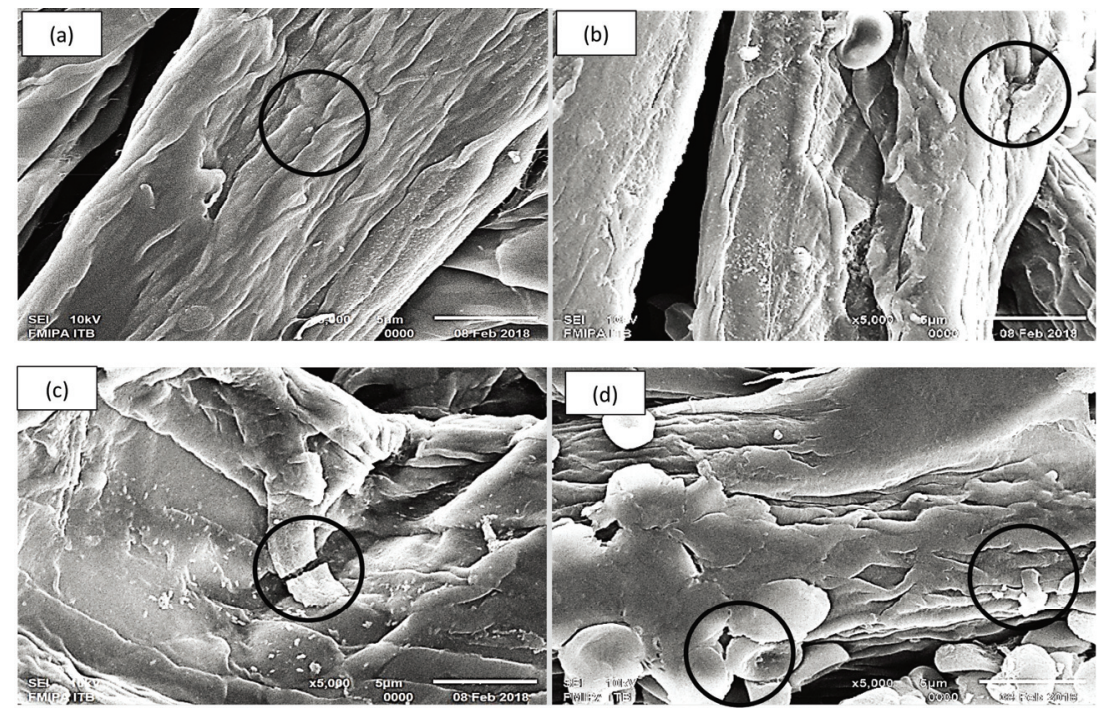

Fig. 5. SEM images of mengkuang pulp after biological pretreatment. (a) Control, (b) biological pretreatment with $10 \%$ inoculum for 15 days, (c) biological pretreatment with $10 \%$ inoculum for 30 days, and (d) biological pretreatment with $10 \%$ inoculum for 45 days.
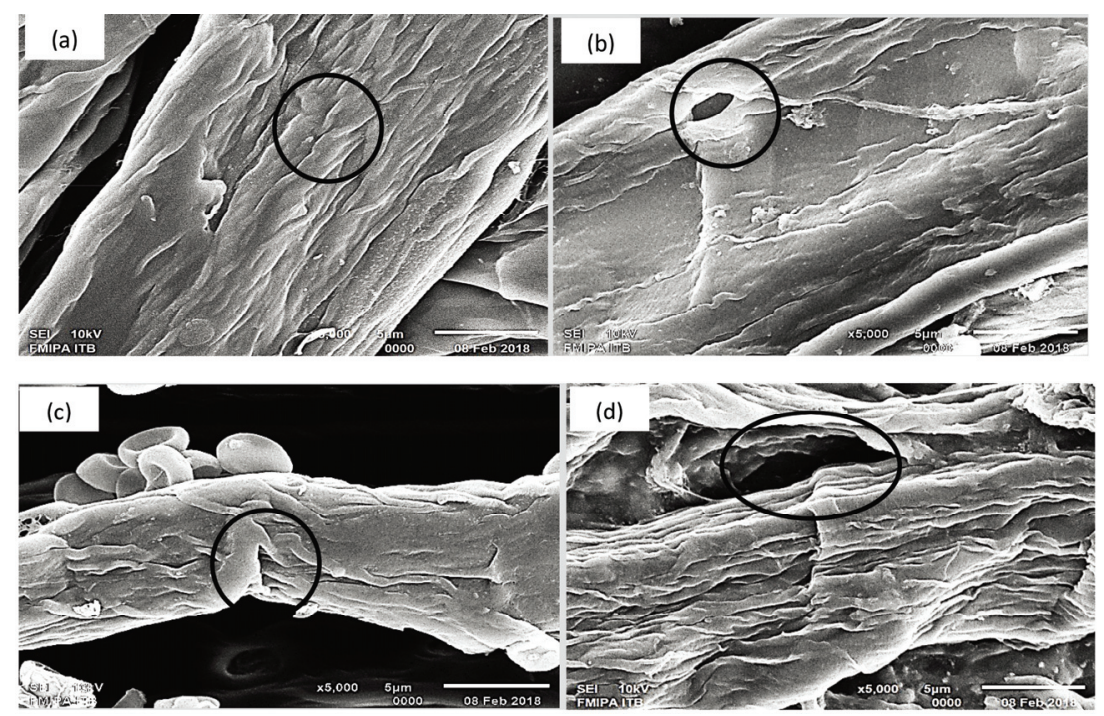

Fig. 6. SEM images of mengkuang pulp after LHW pretreatment. (a) Control, (b) $140^{\circ} \mathrm{C}$ for $30 \mathrm{~min}$, (c) $160^{\circ} \mathrm{C}$ for $30 \mathrm{~min}$, and (d) $180^{\circ} \mathrm{C}$ for $30 \mathrm{~min}$.

sample before and after combination pretreatment (Fig. 7). The biological-LHW combination resulted in damage to the structure of pulp fibers, which were more torn and more porous, indicating that some lignin and hemicellulose components had been degraded (Fig. 7), resulting in an increase in the cellulose surface area 


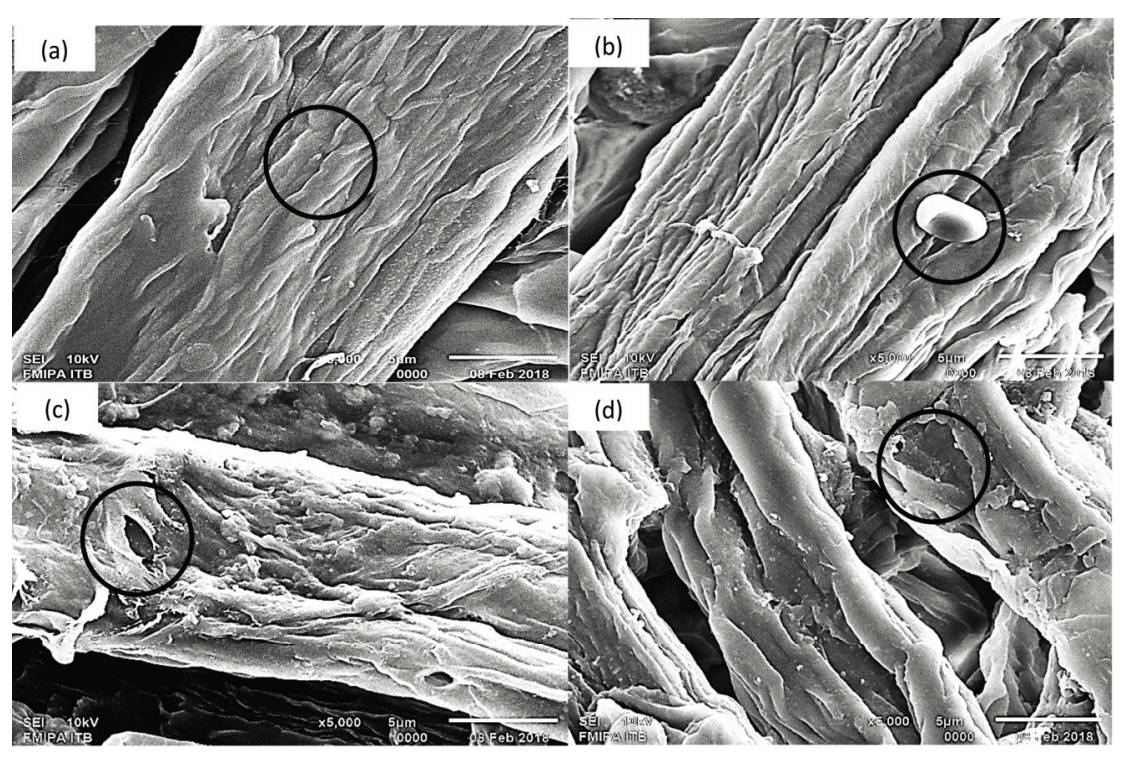

Fig. 7. SEM images of mengkuang pulp after biological-LHW pretreatment. (a) Control, (b) biological pretreatment with $10 \%$ inoculum for 30 days and LHW at $180^{\circ} \mathrm{C}$ for 20 min, (c) biological pretreatment with $10 \%$ inoculum 30 days and LHW at $180^{\circ} \mathrm{C}$ for $30 \mathrm{~min}$, and (d) biological pretreatment with $10 \%$ inoculum for 30 days and LHW at $180^{\circ} \mathrm{C}$ for $40 \mathrm{~min}$.

(Hu and Wen, 2008). The samples suffered little damage to the fiber structure after being pretreated. The breakdown of lignin and hemicellulose polymers within the cell wall as a result of the pretreatment given to the morphological disorganization of the fiber by the increasing number of fibers exposed.

Changes to cell wall morphology due to loss of lignin include a larger pore surface size resulting in better enzyme penetration in cellulose. Degraded lignin and hemicellulose contents resulted in the loss of ether bonds in lignin and LCC, causing fiber separation (Li et al., 2011). Nazarpour et al. (2013) stated that the termination of lignin due to increasing cellulosic digestibility. Examination of plant structures after pretreatment revealed more open structures and brittleness, resulting in greater potential accessibility to cellulase in subsequent hydrolysis.

\subsection{Yields of reducing sugars after pretreatments}

An increase in reducing sugars obtained from SSF would be an indication that pretreatment positively affected cellulose hydrolysis. The breakdown of lignin polymers after biological pretreatment and the resulting fiber damage helped to increase substrate accessibility during the SSF processes. In general, the reducing sugar yield (RSY) obtained after biological-LHW pretreatment $(45.10 \%)$ was higher than after LHWbiological pretreatment (27.18\%; Figs. 8 and 9). Theoretically, the maximum yield of reducing sugar per unit of biomass that can be produced from Jabon wood is $83.24 \%$ with holocellulose $74.2 \%$ with a conversion factor of 1.111 (Fatriasari et al., 2014). The highest reducing sugar content was found in the biological-LHW pretreatment at a temperature of $180^{\circ} \mathrm{C}$ for $30 \mathrm{~min}$ (Fig. 8). The combination of temperature 


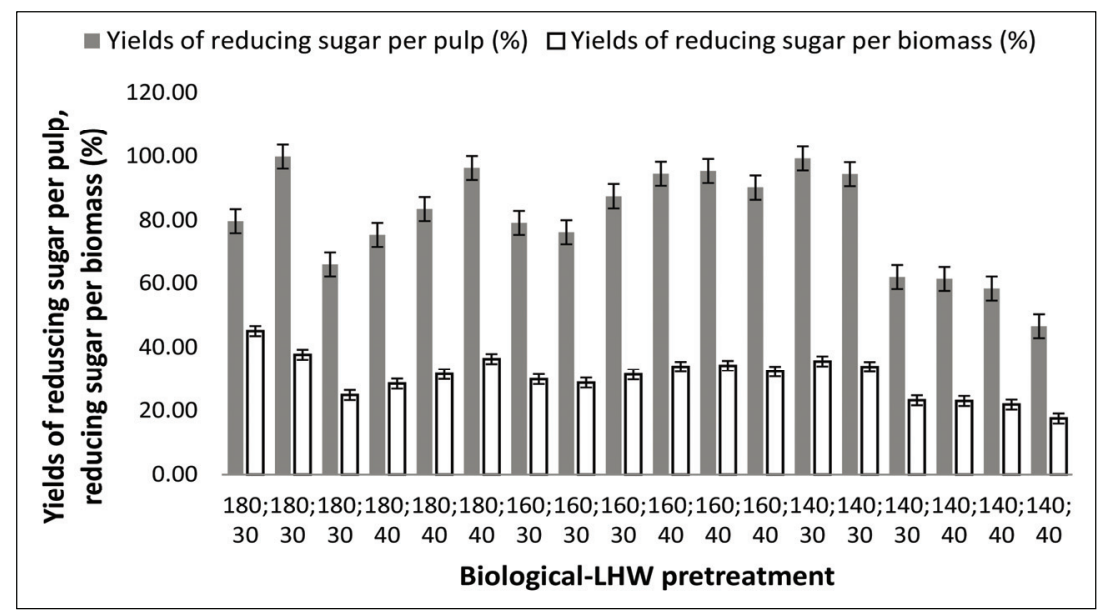

Fig. 8. Reducing sugars resulting from SSF after biological-LHW pretreatment.

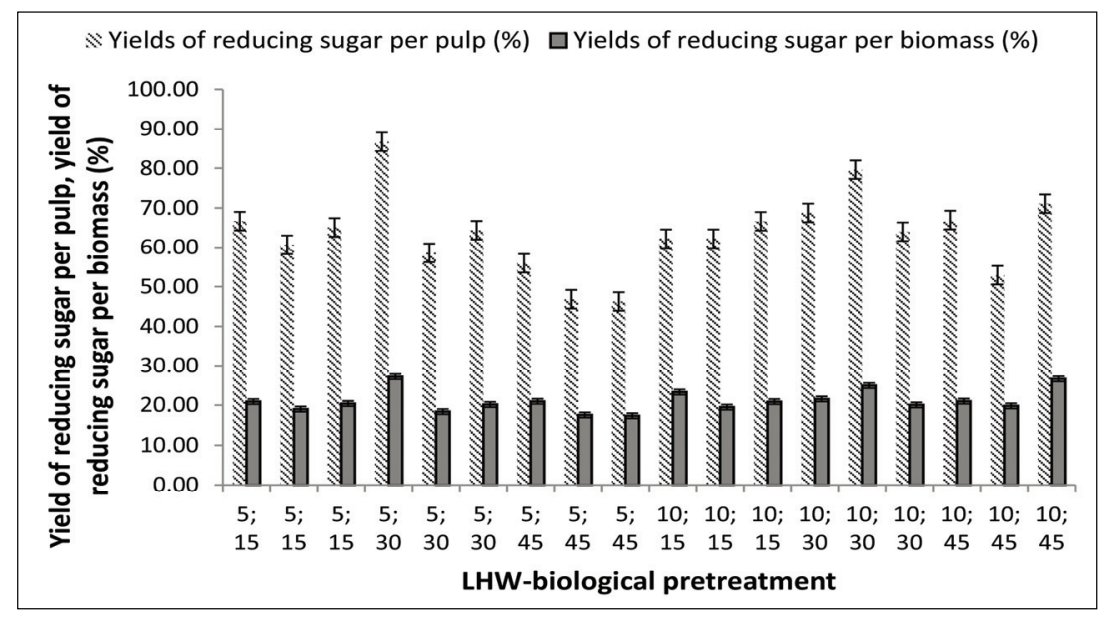

Fig. 9. Reducing sugars resulting from SSF after LHW-biological pretreatment.

treatment and duration of heating in the LHW pretreatment causes the degradation of amorphous components (lignin and hemicellulose), so that cellulose porosity increases, and the more lignin and hemicellulose are degraded, the more the surface of the cellulose is exposed. Subsequently, the accessibility of hydrolytic enzymes during the hydrolysis process will increase and RSY will be higher (Pu et al., 2013). Amin et al. (2014) reported that increasing temperature from $100^{\circ} \mathrm{C}$ to $125^{\circ} \mathrm{C}$ and time variations of 2,4 , and
6 h, did not affect RSY significantly. However, Hongdan et al. (2013) reported that at temperatures of $160-200^{\circ} \mathrm{C}$, temperature increases $s$ positively correlated with glucose and xylan production. The duration of the LHW process also affects the production of sugar, in which the most effective time is $30 \mathrm{~min}$ at $180^{\circ} \mathrm{C}$. The amounts of residual reducing sugar after hydrolysis of pulps with a Klason lignin content of 6.0 and $12.0 \%$ were higher than those from pulps with other Klason lignin values (Wistara et al., 2016). 


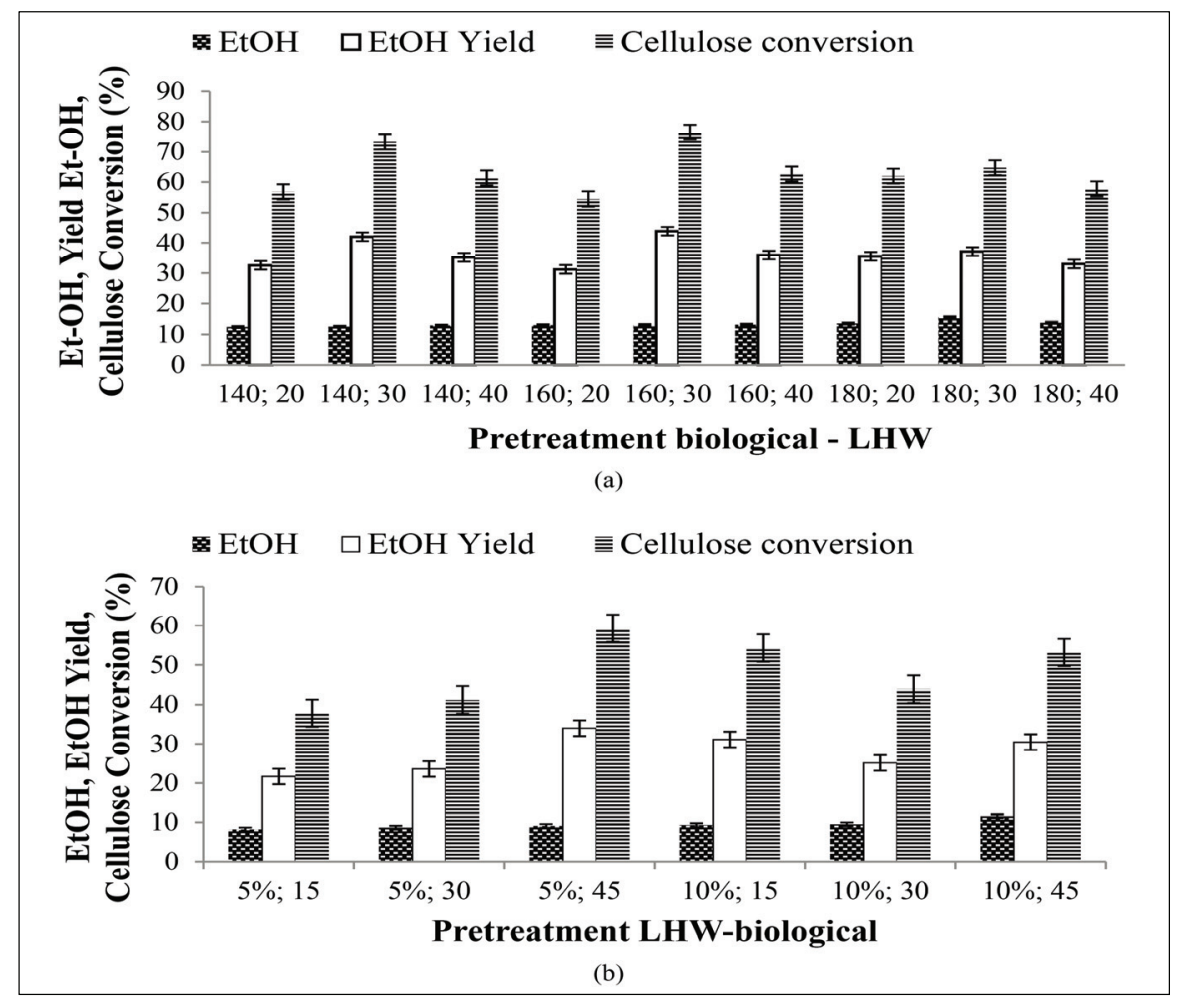

Fig. 10. Ethanol content $(\mathrm{EtOH}(\mathrm{v} / \mathrm{v}) \% \times 10 \times 0.789)$ from SSF after (a) biological-LHW and (b) LHW-biological pretreatments.

\subsection{Ethanol yield}

All pretreated substrates were fermented using $S$. cerevisiae with the aim of identifying the best pretreatment condition for producing ethanol, and the ethanol produced from the biological-LHW SSF pretreatment was relatively higher (Fig. 10a) than that from the LHW-biological pretreatment (Fig. 10b).

The ethanol yield from biological-LHW pretreatment per weight of substrate was $43.86 \%$ (13.11 g/L ethanol), while that from LHW-biological pretreatment was $34.02 \%$ (9.10 g/L ethanol). Ethanol yield from biological-LHW pretreatment at $140{ }^{\circ} \mathrm{C}$ for 20 minutes is $32.57 \%$ (12.44 g/L ethanol), at $140{ }^{\circ} \mathrm{C}$ for 30 minutes is $42.01 \%$ (12.56 g/L ethanol), at $140{ }^{\circ} \mathrm{C}$ for 40 minutes is $35.19 \%$ (12.96 g/L ethanol), at $160{ }^{\circ} \mathrm{C}$ for 20 minutes is $31.23 \%$ (13.04 g/L ethanol), at $160{ }^{\circ} \mathrm{C}$ for 30 minutes is $43.86 \%$ (13.11 g/L ethanol), at $160{ }^{\circ} \mathrm{C}$ for 40 minutes is $35.93 \%$ (13.17 $\mathrm{g} / \mathrm{L}$ ethanol), at $180{ }^{\circ} \mathrm{C}$ for 20 minutes is $35.52 \%$ (13.57 $\mathrm{g} / \mathrm{L}$ ethanol), at $180{ }^{\circ} \mathrm{C}$ for 30 minutes is $37.11 \%$ (13.04 g/L ethanol), at $180{ }^{\circ} \mathrm{C}$ for 40 minutes is $33.01 \%$ (13.78 $\mathrm{g} / \mathrm{L}$ ethanol). Ethanol yield from LHW-biological pretreatment at 5\% inoculum for 15 days is $21.69 \%$ (8.21 $\mathrm{g} / \mathrm{L}$ ethanol), at $5 \%$ inoculum for 30 days is $23.61 \%$ (8.66 $\mathrm{g} / \mathrm{L}$ ethanol), at $5 \%$ inoculum for 45 days is $34.02 \%$ (9.10 g / L ethanol) while at $10 \%$ inoculum for 15 days is $31.14 \%$ (9.31 $\mathrm{g} / \mathrm{L}$ ethanol), at $10 \%$ inoculum for 30 days is $25.17 \%$ (9.52 g / L ethanol), and at 10\% inoculum for 45 days is $30.49 \%$ (11.54 $\mathrm{g} / \mathrm{L}$ ethanol). The use of high temperatures on LHW increases the chances of the formation of hemicellulose degradation which can be 
a barrier in the fermentation process. At a temperature of $150{ }^{\circ} \mathrm{C}$, the amorphous portion of cellulose can be degraded while the new crystalline part can be degraded at a minimum temperature of $180{ }^{\circ} \mathrm{C}$ (Pu et al., 2013).

According to $\mathrm{Yu}$ et al. (2013) LHW pretreatment of bagasse at a temperature of $50{ }^{\circ} \mathrm{C}$, with a maximum control temperature of $170-200{ }^{\circ} \mathrm{C}$ for 20 or $40 \mathrm{~min}$ produces ethanol concentrations of $38.4 \mathrm{~g} / \mathrm{L}$ and 39.4 g/L or yields of $78.6 \%$ and $79.7 \%$, respectively. Cao et al. (2012) also reported that bagasse that was pretreated with diluted $\mathrm{NaOH}$ by autoclaving and in combination with $\mathrm{H}_{2} \mathrm{O}_{2}$ soaking produced a total sugar recovery of $90.94 \mathrm{~g}$ sugar/100 g dry weight and an ethanol concentration of $6.12 \mathrm{~g} / \mathrm{L}$. A research on the removal of fermentation inhibitors from the detoxified hydrolysate by Pichia stipites yielded $4.18 \mathrm{~g} / \mathrm{L}$ ethanol (Um et al., 2016). Cellulose conversion in the study was reported with the stated conditions of $9.2 \%$. Cellulose conversion using the SSF method in this study produced $48.27 \%$ higher than that reported by Wistara et al. (2016). The pretreatment combination that produced the highest RSY was biological-LHW pretreatment at $180{ }^{\circ} \mathrm{C}$ for 30 minutes. The highest RSY value was $45.10 \%$ with ethanol content of 15.5 $\mathrm{g} / \mathrm{L}$. Wistara et al. (2016) reported that an increasing content of ethanol in the SSF system could possibly impede additional hydrolysis because ethanol has been reported to inhibit cellulase activity in the SSF process. The use of high temperature conditions in LHW can lead to hemicellulose degradation, whose products can be inhibitors of the fermentation process. Linde et al. (2008) reported that reducing the lignin content in lignocellulosic materials can increase cellulose hydrolysis, thereby possibly increasing ethanol yield. Successful hydrolysis of cellulose followed by optimum fermentation of the resulting sugars will maximize ethanol production (Qin et al., 2014). Theoretically, the maximum yield for converting reducing sugars into ethanol is $0.51 \mathrm{~g} / \mathrm{g}$ (Wistara et al., 2016).

\section{CONCLUSION}

The delignification and cellulose degradation facilitate hydrolysis process and conversion of cellulose to sugars. The alpha cellulose content of the sample was higher (78.99\%) after biological-LHW pretreatment than that of the LHW-biological pretreatment (76.85\%). The biological-LHW pretreatment combination changed the characteristics of mengkuang pulp by decreasing hemicellulose, lignin, and alpha cellulose contents. The biological-LHW pretreatment decreased hemicellulose and lignin contents by $1.69 \%$ and $3.83 \%$, respectively, and increased alpha cellulose content by $2.14 \%$. Biological-LHW pretreatment resulted in successful degradation, tearing, and increased porosity in the cell wall structures of mengkuang pulp. The RSY was higher for biological-LHW pretreatment (2.02\%) as compared for LHW-biological pretreatment (1.51\%). The highest reducing sugar content was found in the biologicalLHW pretreatment at $180^{\circ} \mathrm{C}$ and $30 \mathrm{~min}$. The biological -LHW pretreatment influenced SSF; thus that the highest RSY was $78.596 \%$ with a concomitant ethanol content of $15.5 \mathrm{~g} / \mathrm{L}$ at $180{ }^{\circ} \mathrm{C}$ and $30 \mathrm{~min}$.

\section{ACKNOWLEDGMENT}

The authors express their gratitude to the Ministry of Research, Technology and Higher Education of the Republic of Indonesia for funding this research through a doctoral dissertation research fund with contract number: 506/UN22.10/PP/2018, 15 February 2018 and domestic postgraduate education scholarship programs counterpart 7 in 1 .

\section{REFERENCES}

Amin, Y., Syafii, W., Wistara, N.J., Prasetya, B. 2014. Pengingkatan rendemen gula pereduksi dari kayu jabon (Anthocephalus cadamba Miq.) dengan 
perlakuan air kapur $(\mathrm{Ca}(\mathrm{OH}))$. Jurnal Ilmu dan Teknologi Kayu Tropis 12(2): 196-206.

Browning, B.L. 1967. Methods of Wood Chemistry. Volume ke-2. New York (US): Interscience.

Canilha, L., Chandel, A.K., Milessi, T.S., Antunes, F.A.F., Freitas, W.L.C., Felipe, A.G.A., Silva, S.S. 2012. Bioconversion of sugarcane biomass into ethanol: an overview about composition, pretreatment methods, detoxification of hydrolysates, enzymatic saccharification, and ethanol fermentation. Journal of Biomedicine and Biotechnology, 2012. 15pages.

Cao, W., Chen, S., Ronghou, L., Renzhan, Y., Xiaowu, W. 2012. Comparison of Effects of Five Pretreatment Methods on Enhancing the Enzymatic Digestibility and Ethanol Production from Sweet Sorghum Bagasse. Bioresource Technology 111: 215-221.

Chen, H., Yejun, H., Jian, X. 2010. Simultaneous Saccharification and Fermentation of Steam Expolded Wheat Straw Pretreated with Alkalie Peroxide. Process Biochemistry 43:1462-1466.

Dence, C.W. 1992. The Determination of Lignin. Di dalam: Lin SY, Dence CW, editor. Methods in Lignin Chemistry. Heidelberg (DE): SpringerVerlag. Hlm. 33-61.

Dowe, N., McMillan, J. 2008. SSF Experimental Protocols - LignocellulosicBiomass Hydrolysis and Fermentation. Technical Report NREL/TP-510 42630.Colorado,US.

Erdei, B., Barta, Z., Sipos, B., Reczey, K., Galbe, M., Zacchi, G. 2010. Ethanol production from mixtures of wheat straw and wheat meal. Biotechnology for Biofuels 3(16): 1-9.

Falah, F., Fatriasari, W., Ermawar, R.A., Nugroho, D.T.A., Hermiati, E. 2011. Effect of corn steep liquor on bamboo biochemical pulping using Phanerochaete chrysosporium. Jurnal Ilmu dan Teknologi Kayu Tropis 9(2): 111-125.

Fajriutami, Y., Fatriasari, W., Hermiati, E. 2016. Pengaruh praperlakuan basa pada ampas tebu terhadap karakteristik pulp dan produksi gula pereduksi. Jurnal Riset Industri 10(3): 147-161.

Fatriasari, W., Ermawar, R.A., Falah, F., Yanto, D.H.Y., Adi, D.T.N., Anita, S.H., Hermiati, E., 2011. Kraft and soda pulping of white rot pretreated betung bamboo. Jurnal Ilmu dan Teknologi Kayu Tropis 9(1): 42-55.

Fatriasari, W., Syafii, W., Wistara, N.J., Syamsu, K., Prasetya, B. 2014. The characteristic chanes of betung bamboo (Dendrocalamus asper) pretreated by fungal pretreatment. International Journal of Renewable Energy Development 3(2): 133-143.

Ferraz, A., Guerra, A. Mendoca, A.R., Masarin, F., Vicentim, M.P., Aguiar, A., Pavan, P.C. 2008. Technological advances and mechanistic basis for fungal biopulping. Enzyme and Microbial Technology 43: 178-185.

Gao, Y., Xu, J., Zhang, Y., Yu, Q., Zhenhong, Y., Liu, Y. 2013. Effect of different pretreatment methods on chemical composition of sugarcane bagasse and enzymatic hydrolysis. Journal Bioresource Technology 144: 396-400.

Giles, R.L, Galloway, E.R., Elliot, G.D. Parrow, M.W. 2011. Oxygen activation during oxidation of methoxyhydroquinones by laccase from Pleurotus eryngii. Bioresource Technology 102: 8011-8016.

Goshadrou, A., Karimi, K., Taherzadeh, M.J. 2011. Improvement of sweet sorghum bagasse hydrolysis by alkali and acidic pretreatment. Wood Renewable Energy Congress. Bioenergy Technology. Linköping Sweden 8-13 May. 374-380.

Hadisuparto, H., Wardenaar, E., Yusro, F., Yanti, H. 2011. Potensi tumbuhan mengkuang dari hutan rawa gambut Kalimantan Barat Sebagai Bahan Baku Pulp dan Kertas. Jurnal Penelitian Universitas Tanjungpura 22(2): 42-57.

Hendriks, A.T.W.M., Zeeman, G. 2009. Pretreatment enhance the digestibility of lignocellulosic biomass: techno-economic performance in short-, middle-, and long-term. Journal of Biomass and Bioenergy 28: 384-410. 
Effect of Biological and Liquid Hot Water Pretreatments on Ethanol Yield from Mengkuang (Pandanus artocarpus Griff)

Heo, J.S., Choi, J.W. 2017. Study on utilization and prospect of lignocellulosic bioethanol in ASEAN countries. Journal of the Korean Wood Science and Technology 45(5): 588-598.

Hong, C.Y., Park, S.Y., Kim, S.H., Lee, S.Y., Ryu, S.H., Choi, I.G. 2016. Biomodification of ethanol organosolv lignin by Abortiporus biennis and its structural change by addition of reducingagent. Journal of the Korean Wood Science and Technology 44(1): 124-134.

Hongdan, Z., Shaohua, X., Subin, W. 2013. Enhancement of enzymatic saccharification of sugarcane bagasse by liquid hot water pretreatment. Journal Bioresource Technology 143(2016): 391-396.

Hu, Z., Wen, Z. 2008. Enhancing enzymatic digestibility of switchgrass by microwave-assisted alkali pretreatment. Biochemical Engineering Journal 38: 369-378.

Li, H.Q., Li, C.L., Sang, T., Xu, J. 2013. Pretreatment on Micanthus lutarioriparius by liquid hot water for efficient ethanol production. Biotechnology for Biofuels 6: 76.

Li, C., Cheng, G., Balan, V., Kent, M.S., Ong, M., Chundawat, S.P.S., Sousa, L.D., Melnichenco, Y.B., Dale, B.E., Simmons, B.A. 2011. Influence of physicochemical changes on enzymatic digestibility of ionic liquid and AFEX pretreated corn stover. Bioresource Technology 102(13): 6928-6936.

Li, X., Ximenes, E., Kim, Y., Slinger, M., Meilan, R., Ladisc, M., Chapple, C. 2010. Lignin monomer composition affects arabidopsis cell-wall degradability after liquid hot water praperlakuan. Biotechnology for Biofuels 3: 27.

Linde, M., Galbe, M., Zacchi, G. 2008. Bioethanol production from non-starch carbohydrate residues in process streams from a dry-mill ethanol plant. Journal Bioresource Technology 99(2008): 65056511.

Long, Sun, S., Jia, L.W., Ming, G.M., Xian, L.S., Run, C.S. 2014. Integated Biorefinery Based on
Hydrothermal and Alkaline Treatments: Investigation of Sorghum Hemicelluloses. Carbohydrate Polymers 111: 663-669.

Michelin, M., Teixeira, J.A. 2016. Liquid hot water pretreatment of multi feedstocks and enzymatic hydrolysis of solids obtains thereof. Bioresource Technology 216: 862-869.

Mosier, N., Wyman, C., Dale, B., Elander, R., Holtzapple, Y.Y.L.M., Ladisch, M. 2005. Features of promising technologies for pretreatmen of lignocellulosic biomass. Bioresource Technology 96: 673-686.

Nazarpour, F., Abdullah, D.K., Abdullah, N., Zamiri, R. 2013. Evaluation of biological pretreatment of rubberwood with white rot fungi for enzymatic hydrolysis. Materials 6: 2059-2073.

Nelson, M.L., O’Connor RT. 1964. Relation of certain infared bands to cellulose crystallinity and crystal lattice type. Part II a new infared ratio for estimation of crystallinity in cellulose I and II. Journal of Applied Polymer Science 8: 1325-1341.

Pandey, K.K., Pitman, A.J. 2003. FTIR studies of the changes in wood chemistry flowing decay by brown-rot and white-rot fungi. International Biodeterioration 52: 151-160.

Pu, Y., Hu, F., Huang, F., Davison, B.H., Ragauskas, A.J. 2013. Assessing the molecular structure for biomass recalcitrance during dilute acid and hydrothermal pretreatments. Biotechnology for Biofuels 6(15): 1-13.

Punyamurthy, R., Sampathkumar, D., Bennehalli, B., Srinivasa, C.V. 2013. Influence of Esterification on the Water Absorption Property of Single Abaca Fiber. Chemical Science Transactions 2: 413-422.

Qin, C., Clarke, K., Li, K. 2014. Interactive forces between lignin and cellulase as determined by atomic force microscopy. Biotechnology for Biofuels 7(65): $1-9$.

Ramos, L.P. 2003. The chemistry involved in the steam treatment of lignocellulosic materials. Quimica Nova 26: 863-871. 
Ravindran, R., Jaiswal, A.K. 2015. A Comprehensive review on pretreatment strategy for lignocellulosic food industry waste: challenges and opportunities. Journal Bioresource Technology 199: 92-102.

Sierra, R., Granda, C.B., Holtzapple, M.T. 2009. Lime Pretreatment. Di dalam: Mielenz J R, editor. Biofuels:Methods in Molecular Biology. 581: 115124. Humana Press

[TAPPI] The Technical Association of the Pulp and Paper Industry. 1997. TAPPI Test Methods. TAPPI Press-Atlanta.

Um, M., Shin, G.J., Lee, J.W. 2016. Enhancement of ethanol production by the removal of fermentation inhibitors, and effect of lignin-derived inhibitors on fermentation. Journal of the Korean Wood Science and Technology 44(3): 389-397.

Wang, L., Han, G., Zhang, Y. 2008. Comparative study of composition, structure and properties of apocynum venetum fibers under different pretreatments. Carbohydrate Polymers 69(2): 391-397

Wang, W., Zhuang, X., Yuan, Z., Qi, W., Yu, Q., Wang, Q. 2016. Structural changes of lignin after liquid hot water pretreatment and its effect on the enzymatic hydrolysis. BioMed Research International 2016: 7pages.

Wistara, N.J., Carolina, A., Pulungan, W.S., Emil, N., Lee, S.H., Kim, N.H. 2015. Effect oftree age and active alkali on kraft pulping of white jabon. Journal of the Korean Wood Science and Technology 43(5): 566-577.

Wistara, N.J., Pelawi, R., Fatriasari, W. 2016. The Effect of Lignin Content and Freeness of Pulp on the Bioethanol Productivity of Jabon Wood. Waste and Biomass Valorization 7(5): 1141-1146.

Yang, H., Wang, K., Ma, J., Yang, J., Shi, Z. 2017. Liquid hot water pretreatment of wheat straw for full carbohydrates biorefinery. BioResources 12(3): 6342-6352.

Yanti, H., Syafii, W., Wistara, N.J., Febrianto, F. 2018. Sifat dasar tanaman mengkuang (Pandanus artocarpus Griff). Jurnal Ilmu dan Teknologi Kayu Tropis. 16(1): 1-14.

Yu, H., Zhang, X., Song, L.K.J., Xu, C., Du, W., Zhang, J. 2010. Evaluation of white rot fungi assisted alkaline/oxidative pretreatment of corn straw undergoing enzymatic hydrolysis by cellulose. Journal of Bioscience and Bioengineering 110(6): 660-664.

Yu, Q., Zhuang, X., Yuan, Z., Wang, W., Qi, W., Wang, Q., Tan, X. 2011. Step change flow rate liquid hot water pretreatment of sweet sorghum bagasse for enhancement of total sugar recovery. Applied Energy 88(7): 2472-2479.

Yu, Q., Zhuang, X., Wang, Q., Qi, W., Tan, X., Yuan, Z. 2012. Hydrolysis of sweet sorghum bagasse and eucalyptus wood chips with liquid hot water. Journal Bioresource Technology 116(2012): 220225.

Yu, Q., Zhuang, X., Lv, S., He, M., Zhang, Y., Yuan, Z., Qi, W., Wang, Q., Wang, W., Tan, X. 2013. Liquid hot water pretreatment of sugarcane bagasse and its compatison with chemical pretreatment methods for the sugar recovery and structural changes. Journal Bioresource Technology 129 (2013): 592-598.

Yu, H., Xing, Y., Lei, Fuhou., Liu, Z., Liu, Z., Jiang, J. 2014. Improvement of the enzymatic hydrolysis of furfural residues by pretreatment with combined. green liquor and ethanol organosolv. Journal Bioresource Technology 167: 46-52.

Zhang, X., Xu, C., Wang, H. 2007. Praperlakuan of Bamboo Residues with Coriolus versicolor for Enzymatic Hydrolysis. Journal of Bioscience and Bioengineering 104(2): 149-151.

Zhuang, X., Wang, W., Yu, Q., Qi, W., Wang, Q., Tan, X., Zhou, G., Yuan, Z. 2015. Liquid hot water pretreatment of lignocellulosic biomass for bioethanolproduction accompanying with high valuable products. Journal Bioresource Technology 199: 68-75. 